\title{
Eosinophilic asthma with chronic rhinosinusitis/nasal polyps and biologic agents
}

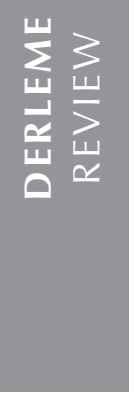

Cite this article as: Yılmaz i. Eosinophilic asthma with chronic rhinosinusitis/nasal polyps and biologic agents. Tuberk Toraks 2019;67(4):292-9.

\section{Yazışma Adresi (Address for Correspondence)}

\section{Dr. Insu YILMAZ}

Erciyes Üniversitesi Tıp Fakültesi,

Göğüs Hastalıkları Anabilim Dalı,

İmmünoloji ve Allerji Hastalıkları Bilim Dalı, KAYSERI - TÜRKIYE

e-mail: insu2004@yahoo.com

CCopyright 2019 by Tuberculosis and Thorax.

Available on-line at www.tuberktoraks.org.com
${ }^{1}$ Division of Immunology and Allergic Diseases, Department of Chest Diseases, Faculty of Medicine, Erciyes University, Kayseri, Turkey

${ }^{1}$ Erciyes Üniversitesi Tıp Fakültesi, Göğüs Hastalıkları Anabilim Dalı, Immünoloji ve Allerji Hastalıkları Bilim Dalı, Kayseri, Türkiye

\begin{abstract}
Eosinophilic asthma with chronic rhinosinusitis/nasal polyps and biologic agents

The current understanding in severe asthma management is the targeted therapy approach with the evaluation of phenotypes and biomarkers. Therefore, personalized treatments are recently more prominent. Eosinophilic asthma with chronic rhinosinusitis/nasal polyps (CRSwNP) is one of the severe asthma phenotypes which needs a personalized treatment approach. Biological agents which specifically target type 2 (T2) high inflammation have been used in this severe asthma phenotype with a preferable safety profile. In the present review, biological agents in eosinophilic asthma with CRSwNP will be discussed.
\end{abstract}

Key words: Severe asthma; eosinophilic asthma; chronic rhinosinusitis/nasal polyp; asthma phenotype; biologics

ÖZ

\section{Kronik sinüzit/nazal polipli eozinofilik astım ve biyolojikler}

Ağır astımda hastalık yönetimi için yeni anlayış fenotip ve biyolojik belirteçlerin kullanılarak hedefe yönelik tedavilerin kullanılmasıdır. Bu nedenle günümüzde kişiselleştirilmiş tedaviler ön plana çıkmaktadır. Kronik rinosinüzit/ nazal polipli (CRSwNP) eozinofilik astım da kişiselleştirilmiş tedavi gerektiren ağır astım fenotiplerinden birisidir. Bu ağır astım fenotipinde tip 2 (T2) high inflamasyonu spesifik bir şekilde hedefleyen ve güvenlik profilleri çok iyi olan biyolojik ajanlar kullanılmaya başlanmıştır. Bu derlemede CRSWNP'li ağır eozinofilik astımda kullanılma potansiyeli olan biyolojik tedaviler ele alınacaktır.

Anahtar kelimeler: Ağır astım; eozinofilik astım; kronik rinosinüzit/nazal polip; astım fenotip; biyolojikler

Asthma patients who are not undercontrol despite treatment with high dose inhaled corticosteroid (ICS) and long-acting $\beta 2$ agonist (LABA) in GINA step 5, need specific asthma management. As the first-line treatment in severe asthma, GINA the recommends addi- 
tion of biologics (for T2 high asthma) and/or long-acting muscarinic antagonists to an ICS + LABA combination. Low dose oral corticosteroid (OCS) usage is recommended as "optional controller therapy" for the prevention of asthma attacks and maintaining asthma control in GINA step $5(1,2)$. The controller options for patients who have uncontrolled severe eosinophilic asthma with CRSwNP despite GINA step 5 treatment are firstly biologic agents and then low dose OCS.

Chronic rhinosinusitis (CRS) affects $5 \%-12 \%$ of the general population. The prevalence of CRSwNP is between $1.1 \%$ and $4.3 \%$ (3). Asthma affects 30\%-70\% of CRSwNP patients. The presence of CRSwNP is associated with the severity of asthma, ranging from $10 \%-30 \%$ in mild asthma to $70 \%-90 \%$ in severe asthma $(4,5)$. CRSwNP in approximately $85 \%$ represents a T2 inflammation (6). CRS and/or nasal polyps are frequently accompanying late-onset severe asthma and the management of this phenotype is quite complex.
Recently, biologic agents are considered preferable rather than low dose OCS in the management of uncontrolled severe eosinophilic asthma with CRSwNP, due to long term serious adverse effects of OCS. In this review, eosinophilic asthma with CRSwNP and suitable biologic agents for the treatment of this specific phenotype will be discussed (Figure 1).

\section{Definations}

Severe asthma: By this is meant that is uncontrolled despite adherence to maximal optimized therapy and treatment of contributory factors, or that worsens when high dose treatment is decreased (1).

Chronic rhinosinusitis: All CRS subjects met the criteria for CRS as defined by the American Academy of Otolaryngology-Head and Neck Surgery Chronic Rhinosinusitis Task Force; the diagnosis of CRS was based on the presence of clinical symptoms (i.e., nasal congestion, rhinorrhea, facial pressure, hyposmia) per-

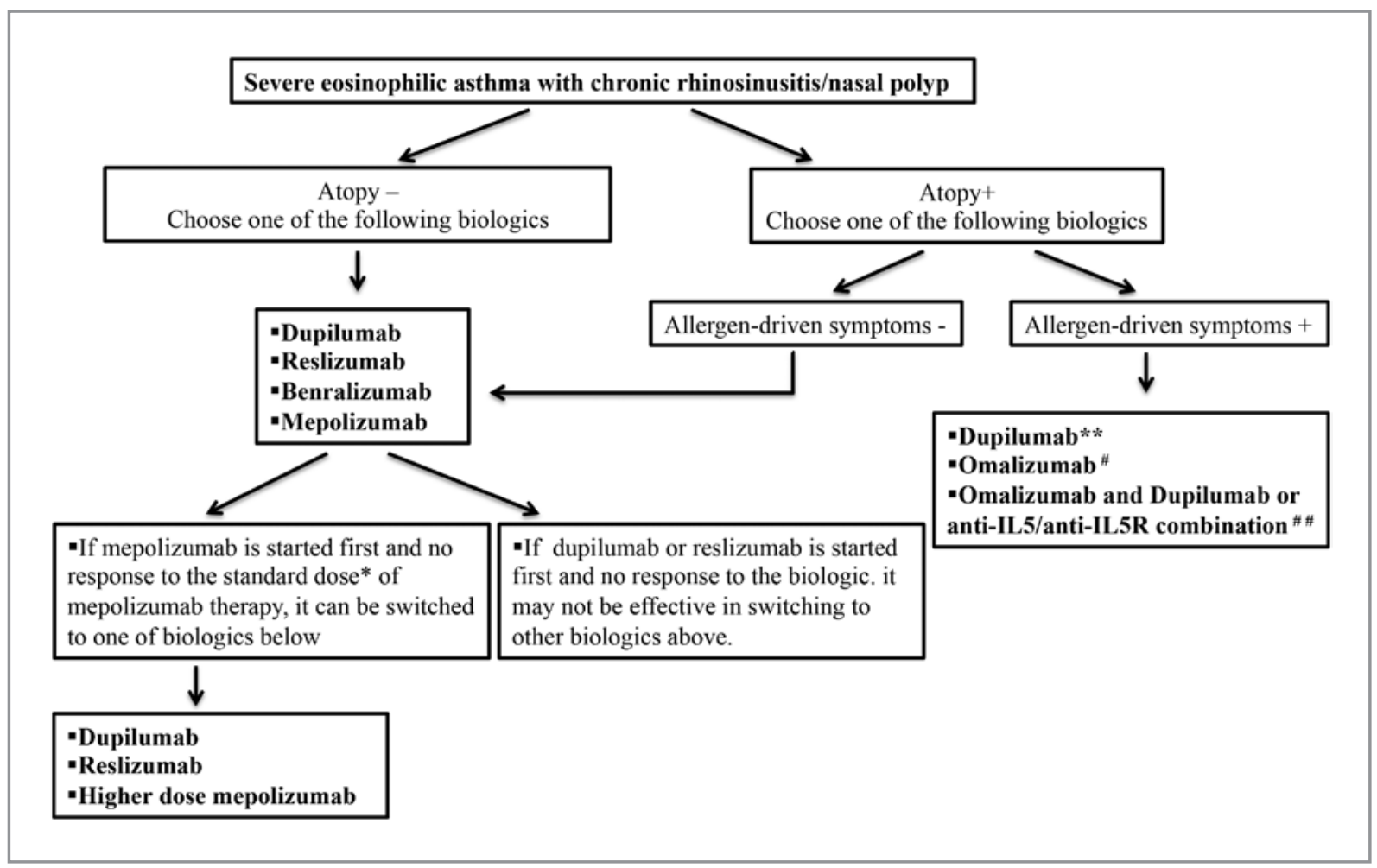

Figure 1. Decision tree for the biologic treatment of the severe eosinophilic asthma with chronic rhinosinusitis/nasal polyp Abbreviations used: Ig: Immunoglobulin; SC: Subcutaneous; IL: Interleukin; IV: Intravenous; FeNO: Fractional exhaled nitric oxide; mg: Miligram; ppb: Parts per billion.

* $100 \mathrm{mg} / \mathrm{month}$, SC.

** First option for patients who have also atopic dermatitis and high FeNO levels ( $\geq 25 \mathrm{ppb}$ ).

\# If patient's atopy status is really appropriate, given the clinical history (childhood allergic asthma, comorbidities such as allergic rhinitis, and respiratory symptoms with exposure to aeroallergens) and patient has high FeNO levels ( $\geq 20 \mathrm{ppb}$ ).

\# Cost-effectiveness? 
sisting for more than 12 weeks in addition to objective evidence of chronic inflammatory disease on paranasal sinus computed tomography (PNCT) imaging or nasal endoscopy (7).

CRSwNP: CRSwNP is characterized by the occurrence for more than 12 weeks of symptoms such as nasal discharge, stuffiness, facial pressure or pain, dysfunction or loss of the sense of smell, and cough from post-nasal drip. It is also characterized the polypoid inflammation filling the nasal cavity in the PNCT (8).

Blood and sputum eosinophilia: Although an established clear threshold for eosinophilic lower airway inflammation still does not exist, it is generally described based on blood or sputum eosinophil levels $(9,10)$. Persistent eosinophilic airway inflammation is one of the best known distinctive disease patterns in asthma and is reflected with the eosinophil number of a minimum of $150-300$ cells per $\mu \mathrm{L}$ in blood and/or more than $2-3 \%$ in sputum (11-15). In fact, blood and sputum eosinophil counts correlate, but blood eosinophil counts are not a stronger indicator of eosinophil counts in the sputum or airway wall $(16,17)$. Although the blood eosinophil count is not a very strong indicator of airway eosinophilia, due to the easy testing method it is still being used in clinical studies (18). The current consensus is that in patients with asthma, a blood eosinophil count of greater than 150 cells $/ \mu \mathrm{L}$ is a good indicator of T2 inflammation and diagnosis of eosinophilic asthma (19).

\section{Asthma Phenotypes and Eosinophilic Asthma with CRSwNP}

Recently, studies on asthma phenotypes and endotypes have been increasing. There is an evolution in asthma classification from simple subtyping, like intrinsic and extrinsic, towards phenotyping which is defined by clinical, laboratory, functional and inflammatory characteristics of the disease and response to treatment. It is now more important to understand asthma phenotypes as there is a new targeted treatment approach with the discovery of new biological agents that were developed for the treatment of underlying inflammation of asthma (20).

Asthma can be arranged into phenotypes according to its clinical and/or observable features. Triggers (allergens or aspirin hypersensitivity), inflammatory cells (eosinophilic, neutrophilic, paucigranulocytic) and comorbid nasal polyposis existence can be given as an example (21-24). Recently, cluster analysis has been used for phenotyping to define more objective criterias and abstain from bias (25-28). Asthma was classifed into 5 phenotypes as below in SARP (Severe Asthma Research Program) which is one of following cluster phenotyping programs: Mild early-onset allergic disease; Moderate early-onset allergic disease; Late-onset eosinophilic nonallergic disease; Severe early-onset eosinophilic allergic disease; Late-onset nonallergic neutrophilic severe asthma with fixed airflow (25). Another characteristic feature of the SARP Cluster 4 late-onset eosinophilic asthma is comorbid chronic rhinosinusitis with nasal polyposis, a feature known for many years and in some cases linked with aspirin and other NSAID hypersensitivity $(29,30)$.

The phenotyping according to inflammation type is closer to asthma pathophysiology, but the underlying mechanism of this inflammation should also be evaluated. For example, in the eosinophilic asthma phenotype, if the main pathway of this inflammation can be determined and correlated with the patient's clinic then we can mention asthma endotypes. The endotype is defined by the correlation of heterogen asthma phenotypes with cellular, molecular, immunological and pathopysological mechanisms (such as atopic asthma with eosinophilia [Th2-mast cell-eosinophilia] or asthma with CRSwNP and eosinophilia [ILC2-IL4/IL5/ IL13-eosinophilia], etc. Endotypes can provide more information about "precision medicine" and "personalized medicine" inlight of asthma pathophysiology $(21,31,32)$. Eosinophilic asthma with CRSwNP has increased with the recognition that in this eosinophilic asthma subtype, high levels of the pro-eosinophilic cytokine IL-5 are produced by a unique population of T2 innate lymphoid cells (33). The main mechanisms are dysregulation of leukotriene synthesis, Staphylococcus aureus enterotoxin-specific IgE and chronic epithelial activation by agents such as superantigens and environmental pollutants, as well as by epithelium-derived innate cytokines (TSLP, IL-25, and IL-33), which stimulates type-2 innate lymphoid cell activation and overproduction of IL-5 (33-37). IL-4 and IL-13 are responsible for relasing chemokine eotaxin that causes the increase of vascular cell adhesion molecule-1 (VCAM-1) expression on the vascular system and enhances eosinophil migration to airway cells, play a role in asthma immunopathobiology (38-42). Hence, eosinophilic asthma with CRSwNP which is related to underlying $\mathrm{T} 2$ high inflammation pathways with clinical inflammatory phenotypes is both asthma endotype and asthma phenotype. 


\section{Eosinophilic Asthma with CRSwNP and Anti-IL5/Anti- IL5R}

In patients with adult-onset asthma, those with high eosinophil counts were more likely to have a greater FENO values, have more sputum eosinophils, be taking oral steroids, have fixed obstruction, have worse lung function, and have a history of chronic rhinosinusitis and nasal polyposis $(14,43,44)$. Both severe eosinophilic asthma and nasal polyposis are characterized by prominent local eosinophilic inflammation (45). IL-5 has an important role in nasal polyp pathogenesis. A nasal polyp is related to the increasing expresssion of IL-5 (45-47). The expression of IL-5 within nasal polyp tissue has been associated with asthma comorbidity (48). Thus, anti-IL5/anti-IL5R mAbs seem to be suitable in the treatment of this phenotype.

In fact, the clinical efficacy of the anti-IL5/anti-IL5R mAbs (mepolizumab, reslizumab, benralizumab) has been reasonably consistent between studies and it is likely that the biologics have very similar effects on eosinophilic severe asthma (49-52). However, this asthma phenotype also has subtypes, like severe eosinophilic asthma with CRSwNP. We also should consider the possibility of different anti-IL5/anti-IL5R treatment responses within all different subtypes. Recent studies have demonstrated that targeting the IL-5 pathway may be efficacious in the treatment of asthma in a subgroup of patients with severe eosinophilic asthma with comorbid CRS (53-55). One of these studies, in a meta-analysis of DREAM and MENSA, assessed the efficacy of mepolizumab versus placebo in patients with severe eosinophlic asthma with or without nasal polyps at baseline. Data from both studies were combined using an inverse-variance weighted fixed-effects meta-analysis. Data are presented for combined $75 \mathrm{mg}$ intravenous and $100 \mathrm{mg}$ subcutaneous mepolizumab doses. A total of 884 patients were included in this analysis, of whom $120(14 \%)$ had nasal polyps at baseline. Patients with nasal polyps had higher blood eosinophil counts at baseline than patients without nasal polyps. The reduction in exacerbations with mepolizumab compared with placebo was 59\% for patients with nasal polyps and $48 \%$ for patients without nasal polyps. Mepolizumab improved ACQ-5, SGRQ, pre-bronchodilator and post-bronchodilator $\mathrm{FEV}_{1}$ versus placebo in both groups, with larger point estimates in the nasal polyps group (53). In another study, a subphenotype which got more benefits from mepolizumab regarding asthma exacerbation reduction was defined. A supervised cluster analysis to determine which patients would benefit most from mepolizumab found
4 clusters. Cluster 2, which had patients with a history of nasal polyps and sinusitis, had a 53\% reduction in exacerbations, whereas cluster 4 patients with obesity and high airway reversibility had a $67 \%$ reduction in exacerbations (56). The effect of benralizumab on this subphenotype was also assesed. A study showed that, compared with placebo, benralizumab reduced exacerbation rates by $42 \%$ for all patients, by $54 \%$ for patients with nasal polyps, and by $38 \%$ for patients without nasal polyps; and increased prebronchodilator FEV $_{1}$ by $0.128 \mathrm{~L}$ for all patients, by $0.272 \mathrm{~L}$ for patients with nasal polyps, and by $0.102 \mathrm{~L}$ for those without nasal polyps in the post-hoc pooled analysis of the Phase III SIROCCO and CALIMA trials. Similar trends were observed for efficacy measures of asthma symptoms and asthma-related quality of life. Benralizumab demonstrated enhanced clinical efficacy for patients with severe, uncontrolled eosinophilic asthma and nasal polyps (57). The efficacy of reslizumab on this subphenotype has been demonstrated in two studies. Reslizumab for the treatment of patients with severe, refractory, eosinophilic asthma was effective in improving lung function and trended toward greater asthma control, especially in patients with nasal polyps (58). In another study, in the post hoc analyses of pooled data from 2 BREATH phase 3 clinical trials, asthma-related outcomes in patients with comorbid, self-reported CRSwNP were examined. Add-on reslizumab treatment reduced the frequency of clinical asthma exacerbations by $83 \%$ versus placebo among patients with CRSwNP. Patients with CRSwNP treated with reslizumab add-on therapy also had significant improvements in lung function, as measured by forced expiratory volume in 1 second, compared with the placebo. Among patients with CRSwNP, reslizumab was also associated with improvements in patient-reported asthma control and asthma quality of life. Patients with eosinophilic asthma and self-reported CRSwNP are highly responsive to treatment with reslizumab for asthma-related outcomes. These findings suggest that a prospective investigation of reslizumab in this patient population is warranted (55). Although these three biological agents (mepolizumab, benralizumab, reslizumab) have a similar effect on eosinophilic asthma with CSRwNP phenotype, reslizumab seems more effective than the others. We believe, in severe eosinophilic asthma with CRSwNP, reslizumab (anti-IL5) could be an alternative treatment option in patients that were unresponsive to mepolizumab. We speculate that the mepolizumab treatment dose might be insufficient to suppress the tissue eosinophilia in these cases and reslizumab might be an alternative treatment option 
due to its dose adjusted according to the patient's weight. Also, mepolizumab has been shown to be an effective treatment for nasal polyposis. In this study, the dosage of the given drug was $750 \mathrm{mg}$, higher than the asthma indication (59). Based on this evidence, increasing the drug dose of mepolizumab before discontinuation might also be an alternative option in this group of asthma patients. However, there is a need for studies that evaluate the comparative effects of mepolizumab $100 \mathrm{mg}$ and $750 \mathrm{mg}$ on this phenotype. In addition, we need high-quality evidence and comparative real-life studies of these biological agents (mepolizumab, reslizumab, benralizumab) to prove this hypothesis in patients with severe eosinophilic asthma with CRSwNP.

\section{Eosinophilic Asthma with CRSwNP and Anti-IL4 $\alpha$}

Dupilumab (anti-IL4 $\alpha$ ) also was considered and discussed as an alternative treatment option in patients with severe eosinophilic asthma with CRSwNP. Targeting the common subunit of the IL-4 and IL-13 receptors has the advantage of blocking multiple other pathways. Although a high blood eosinophil level is still a predictor of response, other predictors, including high FeNO levels, oral steroid dependence, and presence of Type2 comorbidities such as atopic dermatitis and nasal polyposis, may also influence the choice of this biologic" (41). Patients with asthma and comorbid CRS may gain additional benefits from dupilumab treatment as it targets type 2 inflammation associated with these comorbid conditions (42). In a study, Dupilumab 200 mg/300 mg reduced annualized severe exacerbation rates by $63 \% / 61 \%$, respectively, in patients with CRS, and by $42 \% / 40 \%$ in patients without CRS (all $p<0.001$ vs. placebo) (42). With dupilumab treatment, the magnitude of reductions in severe asthma exacerbations and the improvement in $\mathrm{FEV}_{1}$ from baseline was greater in the CRS subgroup than the in non-CRS subgroup. This greater reduction may be due to the simultaneous symptom control of type 2 mediated inflammation of both upper and lower airways by dupilumab leading to improvements in both CRS and asthma outcome measures (42). The findings reported here support and extend the data obtained from a previously published proof-of-concept, phase 2, randomized, placebo-controlled study of dupilumab in patients with CRS and NP (60). Adding dupilumab $300 \mathrm{mg}$ q2 $\mathrm{w}$ to intranasal corticosteroid therapy significantly reduced the burden of NP while improving $\mathrm{FEV}_{1}$ and asthma control, as well as a sense of smell, sinus computed tomography scans, and quality of life in patients with CRS, NP, and comorbid asthma. Phase 3 studies of dupilumab in CRS and NP have recently been completed, confirming and extending these positive results $(61,62)$.

\section{Eosinophilic Asthma with CRSwNP and Anti-IgE}

There are some difficulties in the management of asthma with nasal polyp. Both conditions have similarities like airway eosinophilia, local IgE production and Th2 cytokine profile. Therefore, some studies to evaluate the effect of anti-IgE mAb, omalizumab, in this phenotype have been conducted. In one of these studies, omalizumab has been shown to have positive effects on asthma symptoms and quality of life. However, the primary end point of this study was the reduction in total nasal endoscopic polyp scores after 16 weeks. Secondary end points included a change in sinus computed tomographic scans, nasal and asthma symptoms. There was a significant decrease in total nasal endoscopic polyp scores after 16 weeks in the omalizumab-treated group. Omalizumab had a beneficial effect on airway symptoms (nasal congestion, anterior rhinorrhea, loss of sense of smell, wheezing, and dyspnea) and on quality-of-life scores, irrespective of the presence of allergy. Although omalizumab showed an improvement on asthma symptoms and quality of life in one of the studies, there is not enough evidence to conclude about omalizumab's effect on this subphenotype due to some limitations such as low patient numbers, high drop out ratio in placebo arm, and the evaluation of nasal polyp was the primary endpoint (63).

Asthma symptoms, the number of salbutamol rescue/ week, the number of moderate/severe exacerbations, ACT score, and pulmonary function were significantly improved by the omalizumab in a retrospective, observational, multicentric real-life study evaluating the efficacy of omalizumab in CRSwNP eosinophilic asthma phenotype. In parallel, the sino-nasal clinical outcomes (symptoms, number of acute rhinosinusitis) and the sinus computed tomographic images were significantly improved without an important effect on the nasal endoscopy polyps score. The serum levels of eosinophils were significantly decreased after six months of treatment by omalizumab (64). On the other hand, it has been showed that CRSwNP existence can reduce omalizumab's efficacy in severe allergic asthma (65). Thus, omalizumab seems not to be the first treatment option in patiets having severe eosinophilic asthma with CSRwNP due to lack of enough evidence and lack of large randomised, double-blind, placebo-controlled studies on this condition. 


\section{Which Biologic Agent Should be Used in Severe Atopic Eosinophilic Asthma with CRSwNP}

In clinical practice, especially mixed inflammatory-clinical phenotypes like atopic, severe eosinophilic asthma with CRSwNP, challenge clinicians in choosing the appropriate mAb. In the GINA severe asthma guideline, suggestions were made on which biologic agents should be given for the type 2 high asthma phenotype and it was emphasized that the factors determining the response to treatment should be taken into consideration. It is proposed to consider starting first with an anti-IL5/anti-IL5R in patients with uncontrolled severe asthma with blood eosinophil $\geq 300$ cell $/ \mathrm{mL}$ if; a) Higher blood eosinophils (strongly predictive), b) Higher number of severe exacerbations in previous year (strongly predictive), c) Adult-onset asthma, d) Nasal polyposis, e) maintenance OCS at baseline (1). Patients with severe atopic eosinophilic asthma with CRSwNP, have higher blood eosinophil levels, frequent exacerbation history, and CRSwNP. Therefore, anti-IL5/ anti-IL5R should be the drug of choice in this phenotype of severe asthma group due to possible higher benefit from the treatment eventhough the patients have atopy. On the other hand, anti-IL $4 \alpha$ may also be used in patients with uncontrolled severe severe eosinophilic/Type 2 asthma with blood eosinophils $\geq 150 / \mu \mathrm{L}$ or FeNO $\geq 25$ ppb or need for maintenance OCS if: a) higher blood eosinophils, b) higher FeNO, c) moderate/severe atopic dermatitis, d) nasal polyposis (1). Higher blood eosinophils and nasal polyps which are common predictive factor for both mAbs. Hence, antiIL $4 \alpha$ can be used as a first treatment option for patients who have severe eosinophilic asthma with CRSwNP and atopy, atopic dermatitis or high FeNO levels.

Anti-IgE should be started in patients with uncontrolled severe asthma who are sensitized to inhaled allergen(s) in skin prick testing or specific IgE. The factors that may predict a good response to anti-lgE $\mathrm{mAb}$ are as follows: (a) blood eosinophils $\geq 260 / \mu \mathrm{L}$, (b) $\mathrm{FeNO} \geq 20 \mathrm{ppb}$, (c) allergen-driven symptoms, and (d) childhood-onset asthma. Theoretically anti-IgE can be used in severe atopic eosinophilic asthma with CRSwNP. However, what is important here is whether the patient's atopy status is really appropriate, given the clinical history (childhood allergic asthma, comorbidities such as atopic dermatitis/allergic rhinitis, and respiratory symptoms with exposure to aeroallergens). We think that starting anti-IgE therapy based only on atopy (determination of positivity with skin prick testing and/or determination of specific IgE to common aeroallergens) may not be the ideal approach and that the clinical history should be taken into consideration. On the other hand, CRSwNP existence can reduce omalizumab's efficacy in severe allergic asthma; which is also mentioned in the previous section. Therefore, anti-IL4R $\alpha$ or anti-IL5/anti-IL5R should be preferred for patients who do not have concordant clinical manifestations of atopy or not having childhood-onset atopic asthma in severe atopic/eosinophilic asthma with CRSwNP. If the patient has atopic clinical manifestations and asthma with childhood-onset, omalizumab and anti-IL4R $\alpha$ or anti-IL5/anti-IL5R combination can be suitable but there may be a need for cost-effectiveness studies on this condition.

\section{CONCLUSION}

Anti-IL5/anti-IL5R or anti-IL4R $\alpha$ should be the drug of choice in severe eosinophilic asthma with CRSwNP. Reslizumab and dupilumab seem to stand out in this preference. However, real-life comparative studies are needed to show which of these biological agents should be chosen as the first choice biologic treatment in severe eosinophilic asthma with CRSwNP.

\section{CONFLICT of INTEREST}

The authors reported no conflict of interest related to this articles.

\section{REFERENCES}

1. Diffucult-to-treat and severe asthma in adolescent and adult patients Diagnosis and Management. GINA 2019. www.ginaasthma.org.

2. Asthma management and prevention for adults and children older than 5 years. GINA updated 2019. www. ginaasthma.org.

3. Fokkens WJ, Lund V, Bachert C, Mullol J, Bjermer L, Bousquet J, et al. EUFOREA consensus on biologics for CRSwNP with or without asthma. Allergy 2019;74(12):2312-9.

4. Lin DC, Chandra RK, Tan BK, Zirkle W, Conley DB, Grammer LC, et al. Association between severity of asthma and degree of chronic rhinosinusitis. Am J Rhinol Allergy 2011;25(4):205-8.

5. Shaw DE, Sousa AR, Fowler SJ, Fleming LJ, Roberts G, Corfield J, et al. Clinical and inflammatory characteristics of the European U-BIOPRED adult severe asthma cohort. Eur Respir J 2015;46(5):1308-21.

6. Tomassen P, Vandeplas G, Van Zele T, Cardell LO, Arebro J, Olze $\mathrm{H}$, et al. Inflammatory endotypes of chronic rhinosinusitis based on cluster analysis of biomarkers. I Allergy Clin Immunol 2016;137(5):1449-56.

7. Meltzer EO, Hamilos DL. Rhinosinusitis diagnosis and management for the clinician: a synopsis of recent consensus guidelines. Mayo Clin Proc 2011;86(5):427-43. 
8. Fokkens WI, Lund VI, Mullol I, Bachert C, Alobid I, Baroody F, et al. EPOS 2012; European position paper on rhinosinusitis and nasal polyps. A summary for otorhinolaryngologists. Rhinology 2012;50(1):1-12.

9. Zervas E, Samitas K, Papaioannou Al, Bakakos P, Loukides $S$, Gaga M. An algorithmic approach for the treatment of severe uncontrolled asthma. ERJ Open Res 2018;4(1):00125-2017.

10. Wan XC, Woodruff PG. Biomarkers in severe asthma. Immunol Allergy Clin North Am 2016;36:547-57.

11. Chung KF, Wenzel SE, Brozek IL, Bush A, Castro M, Sterk $P J$, et al. International ERS/ATS guidelines on definition, evaluation and treatment of severe asthma. Eur Respir J 2014;43:343-73.

12. Ortega H, Katz L, Gunsoy N, Keene O, Yancey S. Blood eosinophil counts predict treatment response in patients with severe eosinophilic asthma. I Allergy Clin Immunol 2015;136:825-6.

13. Simpson IL, Scott R, Boyle MJ, Gibson PG. Inflammatory subtypes in asthma: assessment and identification using induced sputum. Respirology 2006;11(1):54-61.

14. de Groot JC, Storm H, Amelink M, de Nijs SB, Eichhorn E, Reitsma BH, et al. Clinical profile of patients with adult-onset eosinophilic asthma. ERI Open Res 2016;2(2):001002015.

15. Belda J, Leigh R, Parameswaran K, O'Byrne PM, Sears MR Hargreave FE. Induced sputum cell counts in healthy adults. Am J Respir Crit Care Med 2000;161:475-8.

16. Hastie AT, Moore WC, Li H, Rector BM, Ortega VE, Pascual $R M$, et al. Biomarker surrogates do not accurately predict sputum eosinophil and neutrophil percentages in asthmatic subjects. I Allergy Clin Immunol 2013;132:72-80.

17. Pizzichini E, Pizzichini MM, Efthimiadis A, Dolovich J, Hargreave FE. Measuring airway inflammation in asthma: eosinophils and eosinophilic cationic protein in induced sputum compared with peripheral blood. I Allergy Clin Immunol 1997;99:539-44.

18. Casale TB, Chipps BE, Rosén K, Trzaskoma B, Haselkorn T, Omachi TA, et al. Response to omalizumab using patient enrichment criteria from trials of novel biologics in asthma. Allergy 2018;73(2):490-7.

19. Kaur R, Chupp G. Phenotypes and endotypes of adult asthma: moving toward precision medicine. J Allergy Clin Immunol 2019;144(1):1-12.

20. Hamilton D, Lehman H. Asthma phenotypes as a guide for current and future biologic therapies. Clin Rev Allergy Immunol 2019.

21. Stokes $J R$, Casale TB. Characterization of asthma endotypes: implications for therapy. Ann Allergy Asthma Immunol 2016;117:121-5.

22. Wenzel SE. Asthma: defining of the persistent adult phenotypes. Lancet 2006;368:804-13.

23. Wenzel SE. Complex phenotypes in asthma: current definitions. Pulm Pharmacol Ther 2013;26:710-5.
24. Wenzel SE. Asthma phenotypes: the evolution from clinical to molecular approaches. Nat Med 2012;18(5):720.

25. Moore WC, Meyers DA, Wenzel SE, Teague WG, Li H, Li X, et al. Identification of asthma phenotypes using cluster analysis in the severe asthma research program. Am J Respir Crit Care Med 2010;181:315-23.

26. Lefaudeux D, De Meulder B, Loza MJ, Peffer N, Rowe A, Baribaud $F$, et al. U-BIOPRED clinical adult asthma clusters linked to a subset of sputum omics. I Allergy Clin Immunol 2017;139:1797-807.

27. Yan X, Chu JH, Gomez J, Koenigs M, Holm C, He X, et al. Noninvasive analysis of the sputum transcriptome discriminates clinical phenotypes of asthma. Am J Respir Crit Care Med 2015;191:1116-25.

28. Simpson IL, Scott R, Boyle MJ, Gibson PG. Inflammatory subtypes in asthma: assessment and identification using induced sputum. Respirology 2006; 11:54-61.

29. Licari A, Brambilla I, De Filippo M, Poddighe D, Castagnoli $R$, Marseglia GL. The role of upper airway pathology as a co-morbidity in severe asthma. Expert Rev Respir Med 2017; 11:855-65.

30. Yilmaz I, Terl M. Asthma management: a new phenotype-based approach using presence of eosinophilia and allergy. Allergy 2017;72:1587-9.

31. Wenzel S. Severe asthma: from characteristics to phenotypes to endotypes. Clin Exp Allergy 2012;42:650-8.

32. Muraro A, Lemanske RF Jr, Hellings PW, Akdis CA, Bieber $T$, Casale TB, et al. Precision medicine in patients with allergic diseases: airway diseases and atopic dermatitisPRACTALL document of the European Academy of Allergy and Clinical Immunology and the American Academy of Allergy, Asthma \& Immunology. I Allergy Clin Immunol 2016;137:1347-58.

33. Morita H, Moro K, Koyasu S. Innate lymphoid cells in allergic and non-allergic inflammation. I Allergy Clin Immunol 2016;138:1253-64.

34. Bachert C, Gevaert P, Holtappels G, Johansson SGO, van Cauwenberge P. Total and specific lgE in nasal polyps is related to local eosinophilic inflammation. I Allergy Clin Immunol 2001;107:607-14.

35. Brusselle GG, Maes T, Bracke KR. Eosinophils in the spotlight: eosinophilic airway inflammation in nonallergic asthma. Nat Me. 2013;19:977-9.

36. Barnes PJ. Intrinsic asthma: not so different from allergic asthma but driven by superantigens? Clin Exp Allergy 2009;39:1145-51.

37. Cahill KN, Boyce JA. Aspirin-exacerbated respiratory disease: mediators and mechanisms of a clinical disease. I Allergy Clin Immunol 2017;139(3):764-6.

38. Gour N, Wills-Karp M. IL-4 and IL-13 signaling in allergic airway disease. Cytokine 2015;75:68-78.

39. Bochner BS, Klunk DA, Sterbinsky SA, Coffman RL, Schleimer RP. IL-13 selectively induces vascular cell adhesion molecule-1 expression in human endothelial cells. I Immunol 1995:154:799-803. 
40. Conroy DM, Williams TJ. Eotaxin and the attraction of eosinophils to the asthmatic lung. Respir Res 2001;2:1506.

41. Pavord ID, Hanania NA. Controversies in allergy: should severe asthma with eosinophilic phenotype always be treated with anti-IL-5 therapies. I Allergy Clin Immunol Pract 2019;7(5):1430-6.

42. Maspero JF, Katelaris CH, Busse WW, Castro M, Corren I, Chipps BE, et al. Dupilumab efficacy in uncontrolled, moderate-to-severe asthma with self-reported chronic rhinosinusitis. J Allergy Clin Immunol Pract 2019.

43. Buhl R, Humbert M, Bjermer L, Chanez P, Heaney LG, Pavord I, et al. Severe eosinophilic asthma: a roadmap to consensus. Eur Respir J 2017;49(5)

44. Coumou H, Bel EH. Improving the diagnosis of eosinophilic asthma. Expert Rev Respir Med 2016;10:1093-103.

45. Bachert C, Wagenmann M, Hauser U, Rudack C. IL-5 synthesis is upregulated in human nasal polyp tissue. J Allergy Clin Immunol 1997;99:837-42.

46. Tomassen P, Vandeplas G, Van Zele T, Cardell LO, Arebro J, Olze $\mathrm{H}$, et al. Inflammatory endotypes of chronic rhinosinusitis based on cluster analysis of biomarkers. J Allergy Clin Immunol 2016;137(5):1449-56.

47. Hamilos DL, Leung DY, Huston DP, Kamil A, Wood $R$, Hamid Q. GM-CSF, IL-5 and RANTES immunoreactivity and mRNA expression in chronic hyperplastic sinusitis with nasal polyposis (NP). Clin Exp Allergy 1998;28(9):1145-52.

48. Bachert C, Zhang N, Holtappels G, De Lobel L, van Cauwenberge $P$, Liu $S$, et al. Presence of IL-5 protein and IgE antibodies to staphylococcal enterotoxins in nasalpolyps is associated with comorbid asthma. I Allergy Clin Immunol 2010;126:962-8.

49. Ortega HG, Liu MC, Pavord ID, Brusselle GG, FitzGerald $J M$, Chetta $A$, et al. Mepolizumab treatment in patients with severe eosinophilic asthma. N Engl J Med 2014; 371:1198-207.

50. FitzGerald IM, Bleecker ER, Nair P, Korn S, Ohta $K$, Lommatzsch $M$, et al. Benralizumab, an anti-interleukin-5 receptor alpha monoclonal antibody, as add-on treatment for patients with severe, uncontrolled, eosinophilic asthma (CALIMA): a randomised, double-blind, placebo-controlled phase 3 trial. Lancet 2016;388:2128-41.

51. Bleecker ER, FitzGerald IM, Chanez P, Papi A, Weinstein $S F$, Barker $P$, et al. Efficacy and safety of benralizumab for patients with severe asthma uncontrolled with high-dosage inhaled corticosteroids and long-acting beta2-agonists (SIROCCO): a randomised, multicentre, placebo-controlled phase 3 trial. Lancet 2016;388:2115-27.

52. Castro M, Zangrilli J, Wechsler ME, Bateman ED, Brusselle GG, Bardin P, et al. Reslizumab for inadequately controlled asthma with elevated blood eosinophil counts: results from two multicentre, parallel, double-blind, randomised, placebo-controlled, phase 3 trials. Lancet Respir Med 2015:3:355-66.
53. Liu MC, Keene ON, Yancey SW, Bratton DJ, Albers FC. Efficacy of mepolizumab in patients with severe eosinophilic asthma and nasal polyps. I Allergy Clin Immunol 2017; 139(2 Suppl):AB8.

54. Maspero J, Harrison T, Werkstrom V, Wu Y, Gopalan G Zangrilli J. Clinical efficacy of benralizumab in patients with severe, uncontrolled eosinophilic asthma and nasal polyposis: pooled analysis of the SIROCCO and CALIMA trials. J Allergy Clin Immunol 2018;141(2519).

55. Weinstein SF, Katial RK, Bardin P, Korn S, McDonald M, Garin $M$, et al. Effects of reslizumab on asthma outcomes in a subgroup of eosinophilic asthma patients with self-reported chronic rhinosinusitis with nasal polyps. I Allergy Clin Immunol Pract 2019;7:589-96.

56. Ortega H, Li H, Suruki R, Albers F, Gordon D, Yancey $S$. Cluster analysis and characterization of response to mepolizumab. A step closer to personalized medicine for patients with severe asthma. Ann Am Thorac Soc 2014:11:1011-7.

57. Maspero J, Harrison T, Werkstrom V, Wu Y, Gopalan G, Zangrilli J. Clinical efficacy of benralizumab in patients with severe, uncontrolled eosinophilic asthma and nasal polyposis: pooled analysis of the SIROCCO and CALIMA trials. J Allergy Clin Immunol 2018; 141(2519 Suppl):AB12.

58. Castro M, Mathur S, Hargreave F, Boulet LP, Xie F, Young J, et al. Reslizumab for poorly controlled, eosinophilic asthma: a randomized, placebo-controlled study. Am J Respir Crit Care Med 2011:184:1125-32.

59. Gevaert $P$, Van Bruaene $N$, Cattaert $T$, Van Steen $K$, Van Zele T, Acke F, et al. Mepolizumab, a humanized anti-IL-5 $m A b$, as a treatment option for severe nasal polyposis. Allergy Clin Immunol 2011;128:989-95.

60. Bachert C, Mannent L, Naclerio RM, Mullol I, Ferguson BJ, Gevaert $P$, et al. Effect of subcutaneous dupilumab on nasal polyp burden in patients with chronic sinusitis and nasal polyposis: a randomized clinical trial. JAMA 2016;315:469-79.

61. Bachert C, Desrosiers M, Mullol J, et al. A randomized phase 3 study, Sinus-52, evaluating the efficacy and safety of dupilumab in patients with severe chronic rhinosinusitis with nasal polyps. J Allergy Clin Immunol 2019;143:AB433.

62. Han JK, Bachert C, Desrosiers M, et al. Efficacy and safety of dupilumab in patients with chronic rhinosinusitis with nasal polyps: results from the randomized phase 3 Sinus24 study. J Allergy Clin Immunol 2019;143:AB42.

63. Gevaert P, Calus L, Van Zele T, Blomme K, De Ruyck N, Bauters $W$, et al. Omalizumab is effective in allergic and nonallergic patients with nasal polyps and asthma. I Allergy Clin Immunol 2013;131(1):110-6.

64. Tiotiu A, Oster JP, Roux P, Nguyen Thi PL, Peiffer G, Bonniaud $P$, et al. Omalizumab's effectiveness in severe allergic asthma and nasal polyps: a real-life study. I Investig Allergol Clin Immunol 2019

65. Sposato B, Scalese M, Milanese M, Masieri S, Cavaliere C, Latorre $M$, et al. Factors reducing omalizumab response in severe asthma. Eur J Intern Med 2018;52:78-85. 